\title{
PŘÍSTUP ČESKOSLOVENSKÉ DIPLOMACIE K IZRAELI V LETECH 1960-1967
}

\author{
EVA TATER OVÁ
}

\begin{abstract}
TATEROVÁ, Eva. The attitude of czechoslovak diplomacy towards Israel in 1960-1967. Historický časopis, 2018, roč. 66, č. 4, pp. 671-700. Bratislava.

The article aims to describe the mutual political and diplomatic relations between Czechoslovakia and the State of Israel in 1960-1967. The period of the 1960s in Czechoslovakia was characterized by a partial liberalization and relaxation of the communist regime in various areas such as politics, economy, culture and so on. This process culminated in the well-known Prague Spring of 1967-1968. By using concrete examples, the author explains whether these changes were reflected by Czechoslovak diplomacy in its attitude towards Israel in any way. Special attention is given to Czechoslovak views on Adolf Eichmann's trial in Jerusalem in 1962, and to the events of the Six Days War in 1967 that led to the official dissolution of Czechoslovak-Israeli diplomatic relations.
\end{abstract}

Key words: Cold War. Czechoslovakia. Diplomacy. Israel. Foreign policy. DOI: https://doi.org/10.31577/histcaso.2018.66.4.5

\section{Úvod}

Politické vztahy mezi Československem a Státem Izrael v období studené války prošly řadou proměn. Období 2. poloviny 40. let 20. století, do kterého časově spadá jak počátek studené války, tak i vznik Státu Izrael a vzestup komunismu v Československu, bylo charakteristické nadstandardně vysokou mírou spolupráce mezi oběma státy. Pokračování přátelských vztahů obou zemí však bylo významně narušeno politickými procesy, které se odehrály v Československu v 1 . polovině 50 . let, přičemž jejich důležitou součást představoval nezastíraný antisemitismus ze strany československých státních autorit a státem ovládaných médií. V této době se bilaterální vztahy obou zemí propadly na pomyslný bod mrazu. ${ }^{1}$

Po ukončení etapy stalinismu a revizi politických procesů, v jejichž rámci došlo k propuštění většiny zadržovaných, následovala etapa určité normalizace československo-izraelských vztahů. Navzdory zvýšení frekvence komunikace

1 ZÍDEK, Petr - SIEBER, Karel. Československo a Blízký východ v letech 1948-1989. Praha: Ústav mezinárodních vztahů, 2009, s. 130-131. ISBN 9788086506760. 
diplomatických představitelů obou zemí je však nutné vzájemné vztahy mezi Československem a Izraelem v 2. polovině 50. let stále označovat jako v lepším případě velmi chladné, $v$ horším případě pak konstantně podezř́vané či dokonce př́ímo nepřátelské. Př́íčiny tohoto vývoje lze hledat především v širších souvislostech dění studené války, kdy Izrael byl v porovnání s prvními roky své existence považován za nezpochybnitelného člena tábora západních zemí. ${ }^{2}$

Cílem tohoto článku je popsat vývoj vzájemných vztahů mezi Československem a Izraelem v letech 1960-1967. Období 60. let v Československu bylo charakteristické určitou liberalizací a uvolňováním komunistického režimu na mnoha úrovních politického, společenského a ekonomického života, které vyvrcholilo známým pražským jarem v letech 1967-1968. Autorka se v této studii zaměří na otázku, zda se tyto změny nějakým způsobem promítly i do přístupu československé zahraniční politiky vůči židovskému státu, eventuálně jakým způsobem se tak v konkrétních př́ípadech dělo.

Pozornost bude věnována především vztahům politickým a diplomatickým, v menší míře pak vztahům kulturním. Ve srovnání s jinými zeměmi, v československo-izraelských vztazích ve sledovaném období nikdy nehrály významnější roli vztahy ekonomické a to především z toho důvodu, že již od počátku 50. let byly obchodní vazby mezi oběma zeměmi v zásadě nulové. Izrael je v kontextu československé zahraniční politiky vůči mimoevropským zemím třeba považovat za unikátní př́padovou studii především vzhledem $\mathrm{k}$ existenci nezanedbatelné židovské menšiny žijící na území Československa. Tento fakt byl jednou z příčin, proč byla geograficky vzdálenému Izraeli v průběhu studené války československou diplomacií věnována určitá politická pozornost.

Události probíhající studené války a velmocenské soupeření v oblasti Blízkého východu stejně jako vnitropolitický vývoj v Izraeli tvoří důležitý kontext pro soudobou československou zahraniční politiku vůči židovskému státu, avšak nejsou samy o sobě předmětem analýzy této studie. Text se bude primárně věnovat rovině československo-izraelských vztahů, přičemž širší záběr dobových událostí a vnitrostátního vývoje v Izraeli bude akcentován pouze v př́padě, kdy to bude nezbytně nutné pro interpretaci soudobé československé zahraniční politiky. S ohledem na dostupnou zdrojovou základnu se bude jednat čistě o československou perspektivu dobových událostí ve vztahu k Izraeli.

\section{Dosavadní zpracování tématu a použité zdroje}

Téma československo-izraelských politických vztahů v 60. letech 20. století je doposud odborně jen velmi málo zpracováno navzdory dostupným poměrně bo-

2 ČEJKA, Marek. Izrael a Palestina: minulost, současnost a směřvání blizkovýchodního konfliktu. Brno: Barrister \& Principal, 2007, s. 264. ISBN 9788087029169. 
hatým archivním zdrojům. $\mathrm{Z}$ existující sekundární literatury lze uvést $\mathrm{v}$ zásadě jen publikaci Československo a Blízký východ v letech 1948-1989³ autorů Petra Zídka a Karla Siebera (2009) a knihu Izrael a Palestina: minulost, současnost a směřvóni blizkovýchodního konfliktu ${ }^{4}$ Marka Čejky (2013). V obou př́padech se však československo-izraelskými vztahy zabývají jen krátké dílčí kapitoly, které mapují základní historické milníky. Především otázce vývoje a podpory sionistického hnutí v Československu se věnuje Moshe Yegar v knize Československo, sionismus, Izrael ${ }^{5}$, avšak bez zpracování dostupných archivních zdrojů.

Tématem, které je akcentováno především v české literatuře, jsou otázky související se statusem Židů na území českých zemí. Velká část těchto publikací jako např́klad sborník Židé v novodobých dějinách ${ }^{6}$ editovaný Václavem Veberem (1997) je věnována historii Židů v českém prostředí primárně v období do 2. světové války. Tento stav má své ospravedlnění zejména vzhledem $\mathrm{k}$ tomu, že po tragédii holocaustu klesly počty Židů v Československu na své historické minimum. Přesto vzniklo také několik publikací, které se věnují postavení Židů v komunistickém Československu. Za nejvýznamnější z nich lze považovat knihu Miloše Pojara, Blanky Soukupové a Marie Zahradníkové (2007) Židovská menšina v Československu v letech 1956-1968: od destalinizace k Pražskému ja$r u{ }^{7}$ Tato kniha je nicméně založená především na výpovědích pamětníků. Téma zahraniční politiky Československa vůči Izraeli je navíc akcentováno jen částečně. Podobným př́ípadem je i kniha Aleny Heitlinger (2007) Ve stínu holocaustu a komunismu: čeští a slovenští židé po roce $1945,{ }^{8}$ která přináší řadu důležitých informací o životě židovské menšiny na území Československa po 2. světové válce. Téma nenávisti vůči Židům v české společnosti akcentuje Jana Svobodová (1994) v publikaci Zdroje a projevy antisemitismu v českých zemích 1948-1992: studie. ${ }^{9}$

3 ZÍDEK, Petr - SIEBER, Karel. Československo a Blízký východ v letech 1948-1989. Praha: Ústav mezinárodních vztahů, 2009, s. 128-148. ISBN 9788086506760.

4 ČEJKA, Marek. Izrael a Palestina: minulost, současnost a směrování blizkovýchodního konfliktu. Brno: Barrister \& Principal, 2007, s. 260-272. ISBN 9788087029169.

5 YEGAR, Moshe. Československo, sionismus, Izrael. Praha: Victoria Publishing, 1997. ISBN 8072190024.

6 VEBER, Václav (ed.). Židé v novodobých dějinách. Praha: Karolinum, 1997. ISBN 8071844128.

7 POJAR, Miloš - SOUKUPOVÁ, Blanka - ZAHRADNÍKOVÁ, Marie. Židovská menšina za druhé republiky: sborník prednášek z cyklu ve Vzdělávacím a kulturním centru Židovského muzea v Praze v lednu až červnu 2007. Praha: Židovské muzeum v Praze, 2007. ISBN 9788086889528.

8 HEITLINGER, Alena. Ve stínu holocaustu a komunismu: čeští a slovenští židé po roce 1945. Praha: G plus G, 2007. ISBN 9788086103976.

9 SVOBODOVÁ, Jana. Zdroje a projevy antisemitismu v českých zemích 1948-1992: studie. 
Kromě výše uvedených zdrojů existuje řada publikací, jejichž primární tematický záměr je jiný než vztahy Izraele a Československa, ale přesto se vybraným bodům věnují. Př́ikladem takových publikací mohou být: Izrael: dějiny ${ }^{10}$ Martina Gilberta (2002), Six Days of War: June 1967 and the making of the modern Middle East Michaea Orena (2010), ${ }^{11}$ kniha Bennyho Morrise (2011) The Righteous Victims: A History of the Zionist-Arab Conflict, 1881-2001, ${ }^{12}$ Arabsko-izraelské války: válka a mír na Blízkém východě od války za nezávislost v roce 1948 po současnost ${ }^{13}$ sepsané bývalým izraelským prezidentem Chajimem Herzogem (2008), My Promised Land: The Triumph and Tragedy of Israeli ${ }^{14}$ napsaná izraelským autorem Ari Shavitem (2013) a kniha Padraiga O'Malleye (2015) The Two-State Delusion: Israel and Palestine - A Tale of Two Narratives. ${ }^{15}$

Současně je nutné uvést odborné publikace, které se věnují obecnějším tématům souvisejícími se zaměřením této studie. Jde o zdroje, které jsou důležité pro pochopení kontextu a mezinárodně-politických souvislostí období let 1960-1967. Jako př́klad lze uvést práci Františka Zbořila (2010) Československá a česká zahraniční politika: minulost a současnost ${ }^{16}$ zajímavé poznatky přináší rovněž kniha Stalin, Izrael a Židé ${ }^{17}$ Laurenta Ruckera (2001). Výčet těchto zdrojů samozřejmě není kompletní vzhledem $\mathrm{k}$ tomu, že $\mathrm{k}$ dispozici $\mathrm{k}$ těmto a dalším tématům existuje bohatý literární fond.

Tento článek se bude opírat prvořadě o pramennou základnu dostupnou v Archivu Ministerstva zahraničních věcí ČR (AMZV), Národním archivu ČR (NA) a v menší míře také v Archivu bezpečnostních složek (ABS). Za hlavní zdrojovou základnu přitom lze považovat archivní materiály dostupné v AMZV. Konkrétně se bude jednat o následující fondy: Teritoriální odbory-obyčejné (TO-O), Izrael, 1960-1964; Teritoriální odbory-tajné (TO-T), Izrael, 1960-1964, TO-T,

Praha: Ústav pro soudobé dějiny AV ČR, 1994. ISBN 9788085270341.

10 GILBERT, Martin. Izrael: dějiny. Praha: BB art, 2002. ISBN 8072577409.

11 OREN, Michael. Six Days of War: June 1967 and the Making of the Modern Middle East. Oxford: Rosetta Books, 2010. ISBN 9780345461926.

12 MORRIS, Benny. The Righteous Victims: A History of the Zionist-Arab Conflict, 1881-2001. New York City: Knopf Doubleday Publishing Group, 2011. ISBN 9780679744757.

13 HERZOG, Chaim. Arabsko-izraelské války: válka a mír na Blizkém východè od války za nezávislost v roce 1948 po současnost. Praha: NLN, Nakladatelství Lidové noviny, 2008. ISBN 9788071069546.

14 SHAVIT, Ari. My Promised Land: The Triumph and Tragedy of Israel. New York City: Spiegel \& Grau, 2013. ISBN 9780385521703.

15 O'MALLEY, Padraig. The Two-State Delusion: Israel and Palestine - A Tale of Two Narratives. New York City: Viking, 2015. ISBN 9780670025053.

16 ZBOŘIL, František. Československá a česká zahraniční politika: minulost a současnost. Praha: Leges, 2010. ISBN 9788087212387.

17 RUCKER, Laurent. Stalin, Izrael a Židé. Praha: Rybka Publishers, 2001. ISBN 8086182533. 
Izrael, 1965-1969 a Politické zprávy Zastupitelský úřad Tel Aviv 1960-1967. Autorka současně využije archiválie dostupné v NA, které se týkají Ústředního výboru Komunistické strany. Konkrétně se jedná o fond Ústředního výboru Komunistické strany Československa 1945-1989, Kancelář 1. tajemníka ÚV KSČ Antonína Novotného - II. část (NA A ÚV KSČ 1945-1989, KTAN-II), k. 109 - Izrael. V ABS lze vzhledem k tématu považovat za stěžejní dvě konkrétní složky týkající se soudního procesu a následné rehabilitace dvou v 50. letech v Československu vězněných Izraelců Mordechaje Orena a Šimona Orensteina. Tyto složky jsou k dispozici pod označením ABS, Archivní protokol vyšetřovacích spisů, č. V-2744 MV a ABS, Zvláštní vyšetřovací spisy - archivní protokol, č. ZV-82.

Především u archivních zdrojů je nutné reflektovat otázku vnitřní kritiky studovaných pramenů. V československém totalitním režimu byl jasně určený diskurz, jakým způsobem uvažovat o probíhající studené válce, a jakou optikou tak mají být hodnoceny jednotlivé kroky izraelské vlády. Zejména po zhoršení vztahů mezi oběma zeměmi na přelomu 40. a 50. let byl československým vyslanectvím v Tel Avivu hodnocen velmi kriticky v zásadě každý krok izraelské vlády s ohledem na vnitrostátní i zahraničně-politické kroky bez ohledu na fakt, zda se tyto konkrétní události nějakým způsobem dotýkaly Československa nebo nikoliv.

Je samozrrejmě legitimní položit si otázku, do jaké míry se jednalo o objektivní hodnocení situace ze strany československých diplomatů, a do jaké míry byli ovlivněni převládající ideologií. Poněkud méně explicitní, ale přesto při detailnějším výzkumu patrné, jsou jednoznačné manipulace s fakty. Týká se to především zpráv shrnujících vývoj vzájemných vztahů mezi Československem a Izraelem, kdy zejména události před rokem 1950 jsou líčeny zcela jinou optikou, než jak je popisují dobové dokumenty. V př́ípadech, kdy to bude možné, budou informace $\mathrm{z}$ archivních zdrojů konfrontovány s dostupnou sekundární literaturou české a zahraniční provenience.

\section{Hlavní milníky vzájemných vztahů do 60. let 20. století Etapa československo-izraelského prátelství}

Historie vztahů československého a židovského obyvatelstva je značně dlouhá a bohatá na události, přičemž první doložené údaje o př́itomnosti Židů ${ }^{18}$ na československém území spadají do 10 . století. ${ }^{19}$ Vzhledem k tématu této studie však

18 V češtině existují dva způsoby, jak psát tento pojem. Zatímco termín Žid s velkým písmenem označuje příslušníka židovského národa, žid s malým písmenem označuje vyznavače judaismu. V mnoha případech se samozřejmě obě tyto kategorie prolínají, ale nemusí tak tomu být vždy. V tomto textu byla zvolena varianta zápisu s velkým počátečním písmenem.

19 WEIN, Martin. History of the Jews in Bohemian Lands. Leiden; Boston: Brill, 2016. ISBN 
lze považovat za stěžejní zejména vývoj ve 20. století, zvláště pak etapu po roce 1918, kdy se Československo etablovalo jako nezávislý stát. V období existence První československé republiky (1918-1938) lze postoj československé politické reprezentace vůči sionistickému hnutí označit za velmi vstř́íný. ${ }^{20}$ Židovská menšina žijící na území Československa disponovala plnými občanskými i politickými právy.

V mezinárodním kontextu bylo významným krokem otevření československého konzulátu v Jeruzalémě $\mathrm{k} 1$. lednu $1926^{21}$ a veřejně deklarovaná podpora sionistickému hnutí prezidentem Tomášem G. Masarykem a dalšími významnými československými představiteli. ${ }^{22} \mathrm{O}$ vzájemně vstřícných a prátelských vztazích vypovídá i skutečnost, že se v letech 1921, 1923 a 1933 na území Československa konaly tři kongresy Světové sionistické organizace. ${ }^{23}$

Situace se diametrálně změnila po rozpadu Československa v důsledku velmocenské politiky nacistického Německa ve 30 . letech. Již od poloviny 30 . let byl patrný vzestup antisemitismu a nepřátelských postojů vůči československým Židům a sionistickému hutí obecně. Eskalace těchto trendů se dále zrychlila v období Druhé československé republiky (záŕí 1938 - březen 1939). Jako hlavní příčiny této změny lze uvést jednak vzrůstající důraz na nacionalismus a češství, což vedlo k netoleranci menšin.

Jako druhý významný prvek vedoucí ke změně postoje některých československých politických představitelů lze spatřovat snahu zavděčit se alespoň v některých ohledech nacistickému Německu. ${ }^{24}$ Postavení československých Židů se diametrálně zhoršilo po březnových událostech roku 1939, kdy došlo k rozdělení Československa na Protektorát Čechy a Morava a Slovenskou republiku, přičemž postavení židovského obyvatelstva v obou částech bývalého Československa vykazovalo určité rozdíly a specifika, která však nejsou předmětem výzkumu tohoto textu. Ve stručnosti je možné konstatovat, že v obou př́padech byla aplikována řada protižidovských opatření založená na principech rasově

9789004301269.

20 MENDELSOHN, Ezra. The Jews of East Central Europe Between the World Wars. Bloomington: Indiana University Press, 1987. ISBN 9780253204189.

21 AMZV TO-O, Izrael, 1945-1959, kart. 9. Generální konsulát v Jerusalemě - zastavení činnosti. Praha, 27. 2. 1952, s. 1. Čj. 106143.

22 ČEJKA, Marek. Theodor Herzl a současné dědictví jeho myšlenek. In HERZL, Theodor. Židovský stát: Pokus o moderní řešení židovské otázky. Praha: Academia, 2009, s. 22. ISBN 9788020017123.

23 ZBOŘIL, František. Československá a česká zahranični politika: minulost a současnost. Praha: Leges, 2010, s. 277. ISBN 9788087212387.

24 Antisemitismus za druhé republiky. In Holocaust, 2015 [online]. Dostupné na internetu: $<$ https://www.holocaust.cz/dejiny/konecne-reseni-zidovske-otazky/zide-v-ceskych-zemich-a-konecne-reseni-zidovske-otazky/antisemitismus-za-druhe-republiky> 
zaměřených Norimberských zákonů a českoslovenští Židé byli těžce zasaženi událostmi holokaustu. ${ }^{25}$

Po skončení 2. světové války mezinárodní společenství sice tragédii holokaustu uznalo, přesto zůstala k řešení otázka, zda mají Židé získat svi̊j vlastní stát a př́ípadně za jakých podmínek. Následně se v roce 1947 Velká Británie, která až doposud oblast Palestiny spravovala jako své mandátní území, rozhodla předat celou záležitost $\mathrm{k}$ projednání nově vzniklé Organizaci spojených národů (OSN). ${ }^{26}$ Československo zastoupené diplomatem Karlem Lisickým se poté stalo členem Zvláštní komise OSN pro Palestinu (UNSCOP) vytvořené v květnu 1947 s posláním navrhnout řešení budoucího uspořádání vztahů mezi Araby a Židy v Palestině. Výsledkem práce této komise byl známý Plán na rozdělení Palestiny, který předpokládal vybudování dvou států, arabského a židovského existujících vedle sebe s tím, že toto řešení mírně favorizovalo požadavky sionistického hnutí. K realizaci plánu ale nikdy nedošlo, protože byl téměř okamžitě po předložení odmítnut arabskou stranou. ${ }^{27}$

Sionistické hnutí vedené pozdějším izraelským premiérem Davidem Ben Gurionem se navzdory ne zcela př́źznivé politické situaci rozhodlo 14. května 1948 v Tel Avivu vyhlásit nezávislý Stát Izrael. ${ }^{28}$ Židovský stát byl téměř okamžitě de iure uznán Sovětským svazem (17. května 1948) a na toto rozhodnutí o den později navázala převážná většina zemí východního bloku včetně Československa. ${ }^{29}$ Již 28. července 1948 se v Praze jako první izraelský vyslanec akreditoval Ehud Avriel..$^{30}$ Československé vyslanectví v Tel Avivu začalo fakticky fungovat až od ledna 1950, kdy do země přijel Eduard Goldstücker rovněž ve funkci vyslance. $^{31}$

Již před deklarací izraelské nezávislosti bylo zřejmé, že nově vzniklý stát s velkou pravděpodobností bude muset svou existenci uhájit ve vojenském střetu

25 JELÍNEK, Tomáš. Pojištovny ve službách hákového křiže: Prosazováni německých zájmů v protektorátním pojištovnictví, arizace pojistek a mezinárodni odškodňování. Praha: Karlova univerzita, Karolinum Press, 2015, s. 182. ISBN 9788024624952.

26 MORRIS, Benny. Making Israel. Ann Arbor: University of Michigan Press, 2007. ISBN 9780745644677.

27 RABINOVICH, Itamar - REINHARZ, Jehuda. Israel in the Middle East: Documents and Readings on Society, Politics, and Foreign Relations, Pre-1948 to the Present. Waltham: UPNE, 2008, s. 61-63. ISBN 9780874519624.

28 Tamtéž, s. 72-74.

29 International Recognition of Israel. In Jewish Virtual Library, 2015 [online]. Dostupné na internetu: <http://www.jewishvirtuallibrary.org/jsource/Peace/recogIsrael.html>

30 ZÍDEK, Petr - SIEBER, Karel. Československo a Blizký východ v letech 1948-1989. Praha: Ústav mezinárodních vztahů, 2009, s. 128. ISBN 9788086506760.

31 GOLDSTÜCKER, Eduard. Vzpomínky: 1945-1968. Praha: G plus G, 2005, s. 40-42. ISBN 8086103870. 
s arabskou opozicí. Z tohoto důvodu již před vznikem Izraele Ben Gurion a další členové sionistického hnutí začali vyjednávat o dodávkách zbraní ze zahraničí. Jako země, se kterou by mělo být možné v tomto směru navázat spolupráci, se jevilo Československo. Na počátku celé transakce sionistické hnutí zastupovala Jewish Agency, kdy neoficiální pověření zahájit vyjednávání obdržel pozdější vyslanec Izraele v Československu Ehud Avriel. ${ }^{32}$

Tyto dodávky zbraní a dalšího vojenského materiálu lze označit za klíčové s ohledem na události první arabsko-izraelské války vzhledem $\mathrm{k}$ faktu, že nově vzniklý Stát Izrael trpěl nedostatkem vojenského vybavení, které si legálně nemohl opatřit $v$ důsledku embarga vyhlášeného Radou bezpečnosti OSN. ${ }^{33}$ Dodávky zbraní a vojenského materiálu z Československa probíhaly v první fázi pod vedením ministerstva národní obrany, kdy finanční hodnota vzájemných smluv uzavřených v letech 1947 a 1948 dosáhla výše 144757 928,37 USD. Po únoru 1948 tyto dodávky probíhaly v koordinaci s ministerstvem zahraničních věcí. ${ }^{34}$ V počáteční etapě československo-izraelských vztahů nebyla významně omezována možnost Židů žijících na území Československa vystěhovat se, pokud o to projevili zájem. Podle interních dokumentů československého ministerstva zahraničních věcí cca 20000 československých Židů svou mateřskou zemi opustilo v letech 1945-1948. Zpráva se odkazuje na izraelské záznamy o počtech nově prríchozích, ale zůstává otázkou, nakolik se jedná o ověřené číslo, což připustil i samotný autor zprávy referent Alois Bartůšek. ${ }^{35}$ Situace se pochopitelně změnila po událostech února 1948, kdy komunistická vláda věnovala značnou pozornost tomu, kdo Československo opouští a z jakých důvodů tak činí. ${ }^{36} \mathrm{~V}$ roce 1948 žilo na území Československa cca 42000 Židů, přičemž dosažení emigrace co největšího počtu z nich bylo považováno za jednu z priorit soudobé izraelské diplomacie. ${ }^{37}$

\section{Ochlazení vzájemných vztahů mezi oběma státy}

Počáteční přátelství mezi Izraelem a státy východního bloku včetně Československa brzy vystřídaly rozpory a stále rostoucí vzájemné odcizování, které vy-

32 DUFEK, Jiří - KAPLAN, Karel - ŠLOSAR, Vladimír. Československo a Izrael v letech 1947-1953: studie. Praha: Doplněk, 1993, s. 11. ISBN 8085270218.

33 GILBERT, ref. 10.

34 DUFEK - KAPLAN - ŠLOSAR, ref. 32.

35 AMZV TO-T, Izrael, 1945-1954. Emigrace do Izraele od roku 1948, 25. 5. 1954, s. 1-3. Čj. 419481.

36 Pokud měla emigrace proběhnout legálně, bylo nutné získat patřičná povolení - bez nich se dotyčný vystavoval riziku obvinění z trestného činu Neoprávněné opuštění území republiky a neuposlechnutí výzvy k návratu, který byl roku 1948 definován v zákoně na ochranu lidově demokratické republiky (Zákon č. 231/1948 Sb., na ochranu lidově demokratické republiky).

37 AMZV TO-O, Izrael, 1945-1959, kart. 9. Vystěhování Židi̊ z Československa. Praha, 4. 12. 1948, s. 1. Čj. 241549. 
vrcholilo v době politických procesů v Československu v první polovině 50. let 20. století. Změna československého přístupu k Izraeli úzce souvisela s následováním sovětského zahraničně-politického kurzu. ${ }^{38}$ Personální čistky, které přišly v období politických procesů iniciovaných Moskvou, měly na vztah Československa k Izraeli velmi negativní dopady. Představitelé židovského státu odsuzovali jak vykonstruovanost procesů, tak i výrazný prvek antisemitismu, který se v jejich průběhu objevoval. Patrně nejznámější je proces vedený proti bývalému generálnímu tajemníkovi Komunistické strany Československa Rudolfu Slánskému a jeho spolupracovníkům, přičemž v průběhu jeho projednávání se opakovaně zdůrazňoval fakt, že 11 ze 14 obviněných bylo židovského původu. ${ }^{39}$

Čistky, které proběhly na počátku 50. let, však nezasáhly pouze část nejvyššího vedení KSČ. Řada československých Židů pak byla v tomto období soudně stíhána a následně vězněna, ačkoliv jejich př́pady nejsou tak známé jak proces se Slánským a jeho skupinou. Mezinárodní pozornost vzbudily př́pady dvou izraelských občanů Mordechaje Orena a Šimona Orensteina, kteří byli v Československu zatčeni v prosinci $1951 .{ }^{40}$ Oba muži čelili obvinění z vazeb na Slánského skupinu, špionážních aktivit a celkově snah poškodit a rozvrátit československý stát, za což byli v 2. polovině roku 1953 odsouzeni k mnohaletým trestům odnětí svobody. Izraelská diplomacie se snažila $\mathrm{v}$ jejich prospěch i prospěch československých Židů intervenovat, avšak její možnosti se $\mathrm{v}$ těchto případech ukázaly jako značně omezené. ${ }^{41}$

Diplomatickou roztržku mezi oběma zeměmi potvrzuje i fakt, že v přímé návaznosti na Orenův a Orensteinův př́ípad byl izraelský chargé d'affaires v Praze Arie L. Kubovy v prosinci 1952 označen československým ministerstvem zahraničních věcí jako persona non grata a byl následně nucen Československo opustit. ${ }^{42}$ Obětí politických procesů se stal i první československý vyslanec v Izraeli Eduard Goldstücker, který byl údajně mimo jiné kvůli svému židov-

38 RUCKER, Laurent. Stalin, Izrael a Židé. Praha: Rybka Publishers, 2001, s. 200-212. ISBN 8086182533.

39 KAPLAN, Karel. Zpráva o zavražděni generálního tajemníka. Praha: Mladá fronta, 1992, s. 149. ISBN 9788020402691; KAPLAN, Karel. Kronika komunistického Československa: Klement Gottwald a Rudolf Slánský. Brno: Barrister \& Principal, 2009. ISBN 9788087029534; LONDON, Artur. Doznání: v soukoli pražského procesu. Praha: Čs. spis., 1990. ISBN 8020202137; SLÁNSKÁ, Josefa. Zpráva o mém muži. Praha: Svoboda, 1990. ISBN 8020501657; STRÖBINGER, Rudolf. Vražda generálního tajemníka : poslední Stalinův exemplárni proces, soud s Rudolfem Slánským. Brno: Petrov, 1991. ISBN 8085247267.

40 ABS, Vyšetřovací spis ORENSTEIN ŠIMON, sv. č. 2, Záznam výpovědi, čj. ZV-171 MV, Praha 13. 12. 1951, s. 1; ABS, Zvláštní vyšetřovací spisy - archivní protokol, Protokol o výpovědi, čj. ZV-82, Praha 8. 1. 1952, s. 1-3.

41 AMZV TO-O, Izrael, 1945-1959, kart. 7. Shimeon Orenstein, Mordecai Oren - zatčení $v$ ČSR. Praha, 20. 5. 1952. Čj. 116566

42 AMZV TO-O, Izrael, 1945-1959, kart. 2. Zpráva ministerstva zahraničnich vecí o vypovězení izr. vyslanca Kubovyho. Praha, 6. 12. 1952, s. 1-2. Čj. 141191 
skému původu po odvolání z Tel Avivu v roce 1951 několik let vězněn. ${ }^{43}$ Podle tvrzení obžaloby měl Goldstücker tvořit spojku mezi Slánského spikleneckým centrem v Praze a Konim Zilliacem, členem britské špionážní služby, ${ }^{44}$ ale s velkou pravděpodobností se jednalo o účelově vykonstruované obvinění. Po Goldstückerově odchodu z Tel Avivu došlo ke snížení úrovně diplomatického zastoupení, kdy jeho nástupce Alois Bartůšek vedl vyslanectví jako chargé d'affaires, ${ }^{45}$ což byl stav, který na československé straně zůstal zachován až do roku 1967.

Situaci dále vyostřily události přelomu let 1952/1953 poté, kdy radikální sionistická skupina Království izraelské provedla několik útoků na budovy československého a sovětského vyslanectví v Tel Avivu. ${ }^{46} \mathrm{~V}$ reakci na tyto události československá diplomacie zcela vážně zvažovala možnost diplomatické styky jako odpověd' na proběhnuvší útoky přerušit. V př́ípadě Sovětského svazu se tak na několik měsíců skutečně stalo. ${ }^{47}$ Československo se nakonec po poradě se sovětskými představiteli rozhodlo diplomatické vztahy s Izraelem zachovat. ${ }^{48}$

Ke krátkému období oteplení československo-izraelských vztahů došlo v 2. polovině 50. let po propuštění obou v Československu vězněných Izraelců Orena a Orensteina ${ }^{49}$ a celkové revizi období stalinismu, přičemž zejména Izrael vkládal do možnosti vylepšení československo-izraelských vztahů velké naděje. To se mimo jiné projevilo v personální obměně na izraelském vyslanectví v Praze - jako nový vedoucí zastupitelského úřadu se akreditoval Šlomo Kaddar. ${ }^{50}$ Tyto naděje se nakonec nenaplnily. Př́íciny je nutné hledat především v širších souvislostech probíhající studené války a regionálním dění na Blízkém východě. Do roku 1956 se datují události Suezské krize, ${ }^{51}$ které kromě eskalace nepřátelství

43 GOLDSTÜCKER, Eduard. Vzpomínky: 1945-1968. Praha: G plus G, 2005, s. 58-62. ISBN 8086103870 .

44 AMZV TO-T, Izrael, 1945-1954. Návrh na úpravu vzájemných vztahů mezi ČSR a Izraelem, 5. 7. 1954, s. 18. Čj. 414306.

45 DEJMEK, Jindřich. Diplomacie Československa: Díl II. Biografický slovník československých diplomatů (1918-1992). Praha: Academia, 2013, s. 279. ISBN 9788020022851.

46 TATEROVÁ, Eva. Aktivity radikální pravicové sionistické skupiny Království izraelské v kontextu československo-izraelských vztahů v 50. letech 20. století. In Rexter, 2015, roč. 13, č. 2, s. 1-24. ISSN 1214-7737.

47 AMZV TO-O, Izrael, 1945-1954, kart. 1. Nota sovětské vlády o přerušení diplomatických styků s izraelskou vládou. Tel Aviv, únor 1953. Čj. Sine.

48 AMZV TO-T, Izrael, 1945-1954, kart. 1. Návrh na úpravu vzájemných vztahů mezi ČSR a Izraelem. Praha, 5. 7. 1954, s. 22-23. Čj. 414306.

49 AMVZ Politické zprávy, ZÚ Tel Aviv, 1956. Řádná politická zpráva za II. čtvrtletí 56. Tel Aviv, 23. 7. 1956, s. 3-4. Čj. 0188.

50 AMZV TO-O, Izrael, 1945-1959, kart. 2. Shelomo Kaddar - vstupní vizum. Praha, 18. 4. 1953. Čj. 114810.

51 ČEJKA, Marek. Izrael a Palestina: minulost, současnost a směřvání blizkovýchodního konfliktu. Brno: Barrister \& Principal, 2007, s. 100. ISBN 9788087029169. 
ve vztazích mezi Izraelem a Egyptem měly významné dopady na mezinárodní politiku v širším měřítku, především pak na vztahy mezi supervelmocemi. Československo po sovětském vzoru okamžitě jednání Izraele a jeho evropských spojenců Francie a Velké Británie odsoudilo, přičemž vzájemné vztahy se opět nevyhnutelně propadly na nezbytně nutnou formální úroveň. ${ }^{52}$

$\mathrm{V}$ této době došlo $\mathrm{k}$ naprostému zastavení židovské migrace $\mathrm{z}$ Československa do Izraele, což bylo ve sledovaném období zcela poprvé..$^{53}$ Vztahy mezi Československem a Izraelem tak zůstaly až do konce 50. let velmi napjaté. Tuto skutečnost dobře deklaruje další diplomatická roztržka vedoucí k vzájemnému vyhoštění diplomatů na jaře roku 1957. Nejprve byl 29. března označen jako persona non grata sekretár̆ archivista izraelského vyslanectví v Praze Moše Schatz kvůli údajné špionáži. ${ }^{54}$ Izraelské ministerstvo zahraničních věcí v reakci na tento př́ípad 2. dubna předalo československému chargé d'affaires Zdeňku Jobánkovi diplomatickou nótu, ve které jej informovalo o prohlášení Jaromíra Vašíčka, attaché zastupitelského úřadu Československa v Tel Avivu, rovněž za persona non grata. Důvodem stejně jako v př́ípadě Schatze měla být prokázaná špionáž. ${ }^{55}$

Po výměně vedoucího zastupitelského úřadu v Praze, kdy v létě 1957 chargé d'affaires Šlomo Kaddara nahradil Šmuel Bendor, se rozhodl Izrael udělat vůči Československu vstřícný krok a přistoupit $\mathrm{k}$ jednostrannému navýšení úrovně diplomatického zastoupení. Bendor tedy přijel do Československa v pozici vyslance. ${ }^{56}$ Československo však k obdobnému kroku nepřistoupilo, i když diskuze o možném navýšení diplomatické úrovně proběhly ještě několikrát, a to většinou v př́ípadě, kdy došlo k personální výměně vedoucího československého zastupitelského úřadu v Tel Avivu jako například v roce 1959, kdy byl dosavadní chargé d'affaires Zdeněk Jobánek vystř́ídán Miloslavem Hrůzou. ${ }^{57}$ Jako hlavní důvody pro odmítnutí se v interní komunikaci uváděla nedůvěra v dobré úmysly Izraele a především obava z narušení vztahů mezi Československem a arabskými státy, které by s velkou pravděpodobností okamžitě odsoudily jakýkoliv náznak československo-izraelské spolupráce. ${ }^{58}$

52 AMZV TO-O, Izrael 1945-1959, kart. 6. Telegram z Tel Avivu. Tel Aviv, 21. 11. 1956. Čj. 145985.

53 NAA ÚV KSČ 1945-1989, KTAN-II, kart. 109. Současný stav a perspektivy vztahư mezi ČSR a Izraelem - Dưvodová zpráva, př́loha III. Praha, 9. 7. 1958, s. 1. Čj. 164.

54 AMVZ TO-T, Izrael, 1955-1959, kart. 1. Protistátní činnost diplomatického pracovnika izraelského vyslanectví v Praze. Praha, 29. 3. 1957, s. 1-3. Čj. 013040.

55 AMVZ TO-T, Izrael, 1955-1959, kart. 1. Vypovězeni s. Vašička z Tel Avivu-protestní nóta. Praha, 9. 4. 1957, s. 1. Čj. 013365.

56 AMZV TO-T, Izrael, 1945-1954, kart. 1. Telegram z Pařǐže. Paříž, 19. 7. 1957. Čj. 124770.

57 DEJMEK, ref. 45.

58 AMZV TO-O, Izrael, 1945-1959, kart. 6. Informace o čs.-izraelských vztazích. Praha, 


\section{Československo-izraelské vztahy v 60. letech 20. století Vztahy mezi Československem a Izraelem na počátku 60. let}

Především 2. polovina 60. let byla v Československu ve znamení uvolnění poměrů a s tím souvisejících společenských změn, přičemž tento proces byl posléze známý pod označením Pražské jaro. Zahraniční politiky, kterou již od roku 1953 ř́́dil ministr Václav David, se však tyto změny dotkly jen v omezené míře. I nadále měly být zachovány úzké vazby na Sovětský svaz a východní blok, zároveň se však jednalo o období, kdy se jednou z priorit československé zahraniční politiky stalo prohlubování politických, ekonomických a kulturních vazeb na vybrané nově dekolonizované země především v Africe a v Asii. ${ }^{59}$

Navázání jakékoliv formy spolupráce samožrejmě podléhalo schválení Sovětským svazem, ale postupem času se podařilo uzavřít několik důležitých dohod o spolupráci $\mathrm{v}$ různých oblastech, především $\mathrm{v}$ oblasti vědecké a technické. V oblasti Blízkého východu a severní Afriky se jednalo např́íklad o dohody s Jemenem (1956), Egyptem (1957), Irákem (1959), Afghánistánem (1960), Spojenou arabskou republikou (1962) a Alžírskem (1963). ${ }^{60}$ Snaha o navázání hlubších vztahů s muslimskými zeměmi logicky vedla k dalšímu vymezování se Československa vůči Izraeli.

Jako konkrétní př́iklad takové situace lze uvést návrh z prvního čtvrtletí iniciovaný československým chargé d'affaires v Izraeli Miloslavem Hrůzou ohledně navýšení diplomatického zastoupení ve vztahu k Izraeli na úroveň vyslance. Tento návrh nejprve získal podporu prezidenta Antonína Novotného, který k Hrůzově zprávě připsal červenou pastelkou následující poznámku: , Uvážit jmenováni vyslance - myslím, že dřivéjši důvody proti z části překonány. " 61 Novotný však posléze změnil své stanovisko na základě doporučení Ministerstva zahraničních věcí, které prohlásilo, že za aktuální situace by takový krok nebyl vhodný. Ministr zahraničních věcí David v dopise Novotnému jako hlavní důvody, proč se k takovému kroku neuchylovat, uvedl hrozbu narušení dobrých vztahů mezi Československem a některými arabskými státy. Přátelské vztahy s arabskými zeměmi byly kromě tradičních důvodů důležité i proto, že Československo v této době usilovalo o podporu těchto států při kandidatuře československého kandidáta Jiřího Noska na post předsedy XV. valného shromáždění OSN. ${ }^{62}$

\footnotetext{
17. 3.1958, s. 5. Čj. sine.
}

59 DEJMEK, Jindřich. Diplomacie Československa: Nástin dějin ministerstva zahraničních věcí a diplomacie (1918-1992). Praha: Academia, 2012, s. 168-172. ISBN 9788020022103.

60 ZBOŘIL, František. Československá a česká zahranični politika: minulost a současnost. Praha: Leges, 2010, s. 254-260. ISBN 9788087212387.

61 A A ÚV KSČ 1945-1989, KTAN-II, kart. 109. Telegram z Tel Avivu. Tel Aviv, 24. 2. 1960. Čj. 2015.

62 NA A ÚV KSČ 1945-1989, KTAN-II, kart. 109. Dopis ministra zahraničních věcí V. Davida 
Druhým významným aspektem, který ovlivňoval československo-izraelské vztahy v 60. letech, bylo postupné sbližování se Izraele a Spolkové republiky Německo (SRN). Přístup sionistického hnutí/Izraele po 2. světové válce k oběma německým státům byl pochopitelně výrazně zatížen událostmi holokaustu. SRN pod vedením kancléře Konrada Adenauera si kladla za cíl přijmout zodpovědnost za zločiny, které byly na Židech nacistickým Německem v minulosti spáchány, a alespoň částečně je odčinit prostřednictvím finančních reparací a další podpory Izraeli. ${ }^{63} \mathrm{~V}$ roce 1965 došlo k oficiálnímu navázání diplomatických vztahů mezi oběma státy, kterému předcházelo postupné sbližování se. ${ }^{64}$ Československo celý tento vývoj sledovalo velmi kriticky, především z toho důvodu, že za výhradního zástupce německého lidu považovalo Německou demokratickou republiku (NDR). ${ }^{65}$ Patrně nejzřetelněji se tento československý př́istup projevil v soudním procesu s Adolfem Eichmannem, kterému bude věnována pozornost $\mathrm{v}$ dalším textu.

Př́stup československé diplomacie vůči židovskému státu ve sledovaném období lze obecně označit jako značně podezřívavý. Událostem, které se Československa týkaly jen okrajově, se často věnovala neúměrně velká pozornost a vždy se očekávaly ty nejhorší možné důsledky. Př́ikladem takové kauzy může být například soudní proces s profesorem Kurtem Sittem obviňovaným Izraelem ze špionážních aktivit, který probíhal v roce 1960. Vzhledem k tomu, že Sitte byl sudetoněmeckým rodákem, tato v Izraeli intenzivně sledovaná kauza opětovně pritáhla pozornost $\mathrm{k}$ Československu. ${ }^{66}$

O tom, že celá záležitost byla československou diplomacií vnímána jako velmi vážná, svědčí i fakt, že ve zprávě zaslané vyslanectvím v Tel Avivu do pražského ústředí se objevilo varování, že ve spojitosti se Sitteho př́padem by mohl být některý z pracovníků vyslanectví označený jako persona non grata. ${ }^{67}$ Tyto obavy se sice nakonec nenaplnily, ale pravděpodobně v návaznosti na negativní vnímání Československa v izraelské společnosti ústředí v Praze neschválilo žádost vedoucího zastupitelského úřadu (ZÚ) Tel Aviv Miloslava Hrůzy o povolení přednášky o Československu ve městě Ramat Gan. Jako důvod se uváděly obavy

prezidentu A. Novotnému ohledně možnosti jmenovat vyslance v Izraeli. Praha, 24. 3. 1960, s. 2-3. Čj. 0063.

63 GILBERT, ref. 10.

64 GARDNER FELDMAN, Lily. The special relationship between West Germany and Israel. Boston: HarperCollins Publishers Ltd, 1984. ISBN 9780043270684.

65 AMZV TO-T, Izrael, 1960-1964, kart. 2. Proces s Adolfem Eichmannem. Praha, 11. 9. 1961, s. 17. Čj. 030428.

66 AMZV TO-T, Izrael, 1960-1964, kart. 1. Zatčení prof. Sitteho v Izraeli-vyžádání informací. Praha, 21. 7. 1960. Čj. 028273.

67 Tamtéž. 
z provokativních otázek na téma československo-izraelských vztahů a možná reciproční žádost o povolení podobné přednášky o Izraeli izraelským vyslanectvím v Praze. ${ }^{68}$

Československé ministerstvo zahraničních věcí se obecně velmi negativně stavělo k pokusům izraelského vyslanectví v Praze navázat kontakt s československými Židy. Koncem roku 1960 československá diplomacie poměrně ostře vystoupila proti skutečnosti, že izraelská ambasáda bez předchozího projednání s československými úřady rozeslala členům židovských obcí dárkové balíčky k židovskému novému roku. V osobním rozhovoru se zástupci ministerstva byl izraelský chargé d'affaires Eliahu Livneh upozorněn, že v př́padě opakování podobných událostí by mohl být prohlášen za persona non grata a vyhoštěn z Československa. ${ }^{69}$

Apel nijak zásadně se nesnažit vylepšovat vztahy Československa s židovským státem potvrdila Koncepce československo-izraelských vztahů schválená kolegiem ministerstva zahraničních věcí 19. května 1961. V koncepci se objevilo následující doporučení: ,, [...] udržovat styky mezi ČSSR a Izraelem takové, jaké jsou, tj. formální a chladné “. ${ }^{70}$ Jako základní podmínka pro možnou normalizaci vzájemných vztahů byla vnímána nutnost zásadní změny směřování izraelské zahraniční politiky, tedy odklon od západních spojenců, což však českoslovenští diplomaté nevnímali jako příliš pravděpodobný scénář. Diplomatické zastoupení mělo byt ponecháno na úrovni chargé d'affaires, pouze v případě pozitivního vývoje arabsko-izraelského konfliktu by se mohlo eventuálně uvažovat o navýšení diplomatického zastoupení na úroveň vyslance. ${ }^{71}$

V polovině roku 1961 došlo k výměně vedoucího československého zastupitelského úruadu v Tel Avivu, kdy Miloslav Hrůza byl vystřídán Milanem Jurzou. Vzhledem ke schválené koncepci vzájemných vztahů Jurza stejně jako předtím Hrůza vedl úřrad i nadále v pozici chargé d'affaires. ${ }^{72}$ Hned po svém př́ijezdu do Izraele byl Jurza konfrontován s další kauzou, která dlouhodobě komplikovala vzájemné československo-izraelské vztahy, a to s dodávkami zbraní z Československa Spojené arabské republice (SAR). Tato věc se stala předmětem rozhovoru Jurzy a izraelské ministryně zahraničních věcí Goldy Meirové 24. července

68 AMZV TO-T, Izrael, 1960-1964, kart. 2. Žádost vedoucího ZÚ Tel Aviv o povolení přednášky o ČSR v Ramat Ganu. Praha, 16. 5. 1960. Čj. 025351.

69 AMZV TO-T, Izrael, 1960-1964, kart. 1. Nežádoucí činnost izraelského ZÚ v ČSSR. Praha, 9. 12. 1960, s. 1. Čj. 031512.

70 AMZV TO-T, Izrael, 1960-1964, kart. 1. Koncepce československo-izraelských vztahů. Praha, 13. 5. 1961, s. 24. Čj. 0245595.

71 AMZV TO-T, Izrael, 1960-1964, kart. 1. Perspektivy styků mezi ČSSR a Izraelem. Praha, 1. 7. 1961, s. 2. Čj. 027735.

72 AMZV TO-T, Izrael, 1960-1964, kart. 1. Záznam o rozhovorech na ministerstvu zahraničnich věcí. Praha, 12. 7. 1961, s. 1. Čj. 0142. 
1961: „Vysvětlil jsem, že ČSSR neprodává nikomu zbraně k agresi, že zbraně dodané SAR jsou určeny k obraně a upevněni nezávislosti SAR. M. poukázala znovu na prohlášení Násira a jiných arabských státníkư a zeptala se, zda tedy je $v$ dohodě uvedeno, že tyto zbraně nesměji být použity $k$ agresi proti Izraeli. Řekl jsem, že jsem dohodu nečetl. " 73

\section{Př́stup Československa $\boldsymbol{k}$ soudnímu procesu s Adolfem Eichmannem}

Hlavní pozornost k Izraeli však v Československu na počátku 60. let poutal soudní proces s nacistickým zločincem Adolfem Eichmannem, který se uskutečnil v Jeruzalémě od 11. dubna do 14. srpna 1962. ${ }^{74}$ Dopadení Adolfa Eichmanna v květnu 1960 agenty izraelské tajné služby Mosad ${ }^{75}$ a jeho následný únos z Argentiny do Izraele vyvolal rozsáhlé ohlasy na mezinárodní scéně. Československo k celé záležitosti zaujalo rozporuplný postoj. Československá diplomacie na jednu stranu nemohla jinak než schválit snahu Izraele potrestat viníky zodpovědné za události holokaustu, avšak současně se bránila jakémukoliv veřejnému prohlášení, které by mohlo být interpretováno jako podpora židovskému státu. ${ }^{76}$

Československo stejně jako další socialistické země odsoudilo porušení státní suverenity Argentiny a mezinárodního práva, ke kterému v kontextu Eichmannova únosu došlo. $\mathrm{V}$ době př́íprav soudního procesu se objevily spekulace, a to nejen v československém tisku, ale i v diplomatickém sboru v Tel Avivu, že Eichmann by mohl být po vyhlášení rozsudku izraelským soudem vydán do některé ze socialistických zemí, kde by byl také souzen za své zločiny v době druhé světové války. Taková praxe se odkazovala na principy definované v Moskevské deklaraci z roku 1943. Uvažovalo se především nad Polskem nebo Mad'arskem, avšak tento předpoklad nakonec nebyl naplněn. ${ }^{77} \mathrm{Na}$ poradě, která se v této věci na ministerstvu zahraničních věcí konala 4. července 1960, byl kritizován mimo jiné i fakt, že Izrael si měl požadavkem soudit Eichmanna uzurpovat právo rozhodovat za světové židovstvo. ${ }^{78}$

73 AMZV TO-T, Izrael, 1960-1964, kart. 1. Rozhovory na MZV. Praha, 9. 8. 1961, s. 2-3. Čj. 0156.

74 ARENDTOVÁ, Hannah. Eichmann v Jeruzalémě: Zpráva o banalitě zla. Praha: Mladá fronta, 1995. ISBN 8020405496.

75 CESARANI, David. Eichmann: jehoživot a zločiny. Praha: Argo, 2008. ISBN 9788072039517; HAREL, Isser. Di̊m v Garibaldiho ulici: dopadení Adolfa Eichmanna. Praha: Paseka, 2003. ISBN 8071855561.

76 AMZV Politické zprávy, Tel Aviv, 1960. Dopadeni válečného zločince Adolfa Eichmanna Izraelem. Tel Aviv, 11. 6. 1960, s. 3. Čj. 0136.

77 AMZV TO-T, Izrael, 1960-1964, kart. 1. Záznam o důležitějšich rozhovorech, pracovníků ZÚ Tel Aviv. Tel Aviv, 10. 3. 1961, s. 13. Čj. 058.

78 AMZV TO-T, Izrael, 1960-1964, kart. 2. Záznam z porady o Eichmannovi. Praha, 5. 7. 1960, s. 2. Čj. 027198. 
Československá diplomacie si po určitou dobu pohrávala s myšlenkou oficiálně požádat ve spolupráci s Mad'arskem a Polskem o vydání Eichmanna do Československa. Nakonec však bylo od této myšlenky opuštěno, především $\mathrm{z}$ důvodu nízkých nadějí na dosažení kladného výsledku. ${ }^{79} \mathrm{Z}$ těchto důvodů nakonec Československo neoficiálně souhlasilo s tím, že s ohledem na utrpení židovského národa během holokaustu by se soud s Eichmannem měl konat v Izraeli, i když dotyčný na tomto území své zločiny nespáchal. ${ }^{80}$ Československo se nicméně oficiálně nepřipojilo $\mathrm{k}$ žalobě $\mathrm{v}$ procesu proti Eichmannovi, především z obav zhoršení vztahů s arabskými státy a Argentinou v př́ípadě uznání prř́slušnosti izraelského soudu. ${ }^{81}$ Současně však Československo př́íslušnost izraelského soudu oficiálně neodmítlo z obavy, že pokud by tak učinilo, bylo možné tento postoj interpretovat jako vyjádření nesouhlasu se zákonností Eichmannova očekávaného odsouzení. ${ }^{82}$

Při př́ípravě soudního procesu proti Adolfu Eichmannovi izraelská strana vznesla požadavek, zda by bylo možné získat z Československa dokumenty mapující zločiny nacizmu ve střední Evropě. Dne 25. srpna 1960 proto československé ministerstvo zahraničních věcí obdrželo od izraelského vyslanectví v Praze diplomatickou nótu, jejímž prostřednictvím izraelská vláda žádala o poskytnutí usvědčujícího materiálu proti Eichmannovi za účelem použití v připravovaném soudním procesu. ${ }^{83}$

Československá diplomacie ve svém postoji k této otázce čelila značnému dilematu. Na jednu stranu československé ministerstvo zahraničních věcí považovalo za nežádoucí, aby Izraeli poskytlo jakýkoliv důkazní materiál proti Eichmannovi at' už oficiální, či neoficiální diplomatickou cestou z obavy, že by to vyslalo signál o spolupráci mezi oběma zeměmi. Současně si však Československo neprrálo vzbudit dojem, že dokumenty o Eichmannových zločinech nechce vydat a tím pádem tak válečného zločince nepř́mo podporuje. ${ }^{84}$

Celá záležitost nakonec byla vyřešena určitým kompromisem. V odpovědi na izraelskou nótu z 25. srpna 1960 československé ministerstvo zahraničních věcí odpovědělo, že prŕijezd zvláštního izraelského vyslance ve věci Eichmanna do

79 Tamtéž, s. 4.

80 AMZV TO-T, Izrael, 1960-1964, kart. 2. Proces s Adolfem Eichmannem. Praha, 11. 9. 1961, s. 15. Čj. 030428.

81 AMZV TO-T, Izrael, 1960-1964, kart. 2. Záznam z porady o Eichmannovi. Praha, 5. 7. 1960, s. 2. Čj. 027198.

82 NA A ÚV KSČ 1945-1989, KTAN-II, kart. 109. Postoj ČSSR a ostatních socialistických zemí k připadu nacistického zločince A. Eichmanna. Praha, 12. 8. 1960, s. 4. Čj. 018130.

83 AMZV TO-T, Izrael, 1960-1964, kart. 1. Nota izraelského vyslanectví s požadavkem vydání materiálů o Eichmannovi. Praha, 6. 10. 1960. Čj. 030100.

84 AMZV TO-T, Izrael, 1960-1964, kart. 2. Záznam z porady o Eichmannovi. Praha, 5. 7. 1960, s. 3. Čj. 027198. 
Československa není nutný, protože československé úřady již důkazní materiály samy sbírají. Současně se začala připravovat tisková konference Svazu protifašistických bojovníků, který měl důkazy o Eichmannových zločinech na území Československa veřejně prezentovat. Účast na této konferenci, která se uskutečnila 3. listopadu 1960, byla umožněna i mezinárodnímu tisku. Svaz protifašistických bojovníků byl vybrán jako zprostředkovatel z toho důvodu, že oficiálně nebyl československou státní institucí, i když pochopitelně všechna jeho činnost státnímu aparátu plně podléhala. ${ }^{85}$

V soudním procesu s Eichmannem tvořil dvanáctý bod z patnácti bodů obžaloby zničení vesnic Lidice a Ležáky a následný osud jejich obyvatel. Z Československa se na soudní projednávání těchto záležitostí nedostavil žádný svědek, a to především kvưli chybějící oficiální podpoře československé vlády. ${ }^{86}$ Československo stejně jako další socialistické země od počátku příprav procesu kritizovalo údajně neadekvátně koncipovanou obžalobu, kde mělo dojít $\mathrm{k}$ vážnému zkreslení či přímo zamlčení některých podstatných událostí či podílů dalších osob zodpovědných za události holokaustu - jedním z často uváděných jmen byl Hans Globke, poradce západoněmeckého kancléře Konrada Adenauera. ${ }^{87}$

$\mathrm{Z}$ těchto důvodů byl Československem soudní proces a jeho výsledky hodnocené jako nedostatečné. Československý chargé d'affaires v Izraeli Miloslav Hrůza komentoval výsledky soudního procesu následovně: ,Eichmannưv proces byl jedinečnou př́ležitostí pro odhaleni zejména žijicích nacistů, zastávajících dnes vysoké funkce v NSR a v NATO. Právě proto ho ve světě očekávali s tak nevšedním zájmem. Tato jedinečná př́ležitost nebyla plně využita a to v rozhodujicí míre vinou způsobu vedení procesu státním prokurátorem, jež postupoval podle směrnic vlády. "88

\section{Vývoj vztahů Československa a Izraele do roku 1967}

Po skončení soudního procesu s Adolfem Eichmannem, který jak bylo vysvětleno $\mathrm{v}$ předchozím textu, přinesl nový podnět do československo-izraelských vztahů, následoval návrat k běžné agendě. Vztahy mezi oběma zeměmi zůstaly i nadále chladné, ale až do událostí šestidenní války v roce 1967 se neobjevily žádné další vysoce kontroverzní kauzy, které by vedly k opětovnému vyostření situace, tak jak tomu bylo v 50. letech.

85 AMZV TO-O, Izrael, 1960-1964, kart. 1. Dopis israel. vyslanectví, týkající se materiálů proti Eichmannovi. Praha, 11. 11. 1960. Čj. 129510.

86 AMZV TO-T, Izrael, 1960-1964, kart. 2. Proces s Adolfem Eichmannem. Praha 11. 9. 1961, s. 13. Čj. 030428.

87 Tamtéž, s. 17.

88 Tamtéž, s. 17. 
V únoru 1962 československé vyslanectví v Tel Avivu zaslalo do pražského ústředí rozsáhlý dokument nazvaný Rozbor zahraničnopolitických cielov Izraela v roku 1962 a návrhy na náš postup, ve kterém byly formulovány některé klíčové zásady soudobých vzájemných vztahů. Stejně jako v předchozích letech byl i v roce 1962 Izrael považován za agenta kapitalistických a koloniálních velmocí především s ohledem na svou roli v nově nezávislých zemích Afriky a jihovýchodní Asie. Dále se předpokládala opakovaná kritika Československa za dodávky zbraní a dalšího vojenského materiálu vybraným arabským zemím. ${ }^{89}$

S ohledem na vztahy $\mathrm{k}$ lidově demokratickým státům československé vyslanectví v Tel Avivu charakterizovalo př́stup Izraele jako kombinaci kritiky socialistického zřízení a stížností na neuspokojivé postavení Židů v těchto státech. Izrael měl zároveň projevovat konstantní úsilí o zlepšení vzájemných vztahů s cílem vyvolat rozkoly mezi socialistickými státy a jejich arabskými spojenci. Československo Izrael současně obviňovalo ze snahy využít židovské obyvatelstvo na území lidově demokratických státu pro špionáž ve prospěch západních kapitalistů. ${ }^{90} \mathrm{~V}$ části dokumentu věnované doporučením ohledně dalšího postupu autoři textu konstatovali, že je žádoucí i nadále pokračovat v dodávkách zbraní arabským státům vzhledem $\mathrm{k}$ tomu, že tyto země bojují proti světovému imperialismu. ${ }^{91}$ Návrhy izraelských představitelů na zlepšení vzájemných vztahů měly být odmítány jako neupřímné a neodpovídající skutečnosti. Československé úruady současně měly co nejvíce bránit vzájemným kontaktům mezi Izraelem a židovským obyvatelstvem v Československu, které byly považovány za potenciálně nebezpečné, a proto nežádoucí..$^{92}$

$\mathrm{Na}$ základě tohoto dokumentu a zásad definovaných v Koncepci československo-izraelských vztahů z roku 1961 československá diplomacie odmítala v zásadě všechny návrhy izraelské strany. Izraelský chargé d’affaires Eliahu Livneh i jeho následovník Jehuda Nassie, ${ }^{93}$ který se $\mathrm{v}$ Praze akreditoval v roce 1963 a zastával pozici vedoucího místní izraelské diplomatické mise až do roku 1967, opakovaně přicházeli na československé ministerstvo zahraničních věcí s náměty na rozvoj politických, ekonomických a kulturních vztahů s Československem. ${ }^{94}$ Všechny tyto apely však byly bezúspěšné.

89 AMZV TO-T, Izrael, 1960-1964, kart. 1. Rozbor zahraničnopolitických ciel'ov Izraela v roku 1962 a návrhy na náš postup. Praha, 13. 2. 1962, s. 3-4. Čj. 021.

90 Tamtéž, s. 6.

91 Tamtéž, s. 7.

92 Tamtéž, s. 9.

93 NA A ÚV KSČ 1945-1989, KTAN-II, kart. 109. Záznam o návštěvě chargé d'affaires Izraele p. Yehuda Nassie, u s. I. Náměstka dr. A. Gregora dne 30. srpna 1963. Praha, 31. 8. 1963. Čj. 011167.

94 Např. AMZV TO-T, Izrael, 1960-1964, kart. 1. Záznam o návštěvě chargé d'affaires Izraele 
Tradiční pozornost byla samožrejmě jak československou, tak izraelskou stranou věnována otázce emigrace československých Židů do Izraele. Ve zprávě pro schůzi kolegia ministerstva zahraničních věcí 14. února 1963 se objevila informace, že v předchozích letech bylo vystěhovalectví povolováno pouze za účelem slučování rodin a osobám přestárlých. Jak v roce 1961, tak i v roce 1962 se vždy mělo jednat o 53 osob, které se do Izraele skutečně vystěhovaly. ${ }^{95} \mathrm{~V}$ porovnání s předchozí etapou, kdy byla emigrace umožňována výhradně vybraným jednotlivcům, se jednalo o určitý početní nárůst. ${ }^{96}$

V roce 1963 tento počet dokonce ještě vzrostl na 157 osob. Záležitost vystěhovalectví vždy vyžadovala součinnost několika státních institucí. Dne 11. června 1964 ministerstvo zahraničních věcí vzneslo požadavek, aby do budoucna nebyly navyšovány počty vystěhovalců od Izraele, současně vystěhovalectví nemělo být povolováno osobám mladšího věku. Tento postup byl oficiálně schválen náměstkem ministra zahraničních věcí Jánem Pudlákem. $\cdot{ }^{97} \mathrm{~V}$ realitě se však toto ustanovení nerespektovalo, protože v roce 1964 počet vystěhovaných dále vzrostl na 599 osob, v období 1. ledna - 1. května 1965 se jednalo o 106 československých občanů..$^{98}$

Za určitou formu zadostiučinění pro Izrael ve vztahu k Československu lze považovat znovuotevření debaty ohledně politických procesů z 50 . let. V izraelské společnosti i politice byla této záležitosti dlouhodobě věnována velká pozornost, protože revize období politických procesů v socialistických zemích byla vnímána jako velká prŕíležitost na očištění sionistického hnutí v těchto státech. ${ }^{99}$ Téma možného znovuotevření a přehodnocení politických procesů reflektováno jak v izraelských médiích, tak i při setkání československých diplomatů s jejich izraelskými protějšky. Představovalo např́íklad významnou náplň rozhovoru při

p. Livneha u vedoucího 9. odboru s. Kožušnika dne 7. února 1962. Praha, 9. 2. 1962. Čj. 022477; AMZV TO-T, Izrael, 1960-1964, kart. 1. Záznam o přijetí chargé d'affaires Izraele p. Nassie u vedoucího 9. odboru s. Jablonského dne 19. listopadu 1963. Praha, 20. 11. 1963, s. 1. Čj. 031375; AMZV TO-T, Izrael, 1960-1964, kart. 1. Záznam o přijetí chargé d'affaires Izraele p. Nassie u vedoucího 9. odboru s. Jablonského dne 19. listopadu 1963. Praha, 20. 11. 1963, s. 3. Čj. 031375.

95 AMZV TO-T, Izrael, 1960-1964, kart. 1. Izrael - Vystěhovalectví z ČSSR do Státu Izrael. Praha, 12. 11. 1964, s. 1. Čj. 029635.

96 AMZV TO-O, Izrael, 1945-1959, k. 6. Informace o čs.-izraelských vztazích, 17. 3. 1958, Poláček, s. 3. Čj. sine.

97 AMZV TO-T, Izrael, 1960-1964, kart. 1. Izrael - Vystěhovalectví z ČSSR do Státu Izrael. Praha, 12. 11. 1964, s. 1. Čj. 029635.

98 AMZV TO-T, Izrael, 1965-1969, kart. 1. Dưvodová zpráva. Praha, 10. 8. 1965, s. 3. Čj. 026422.

99 AMZV TO-O, Izrael, 1960-1964, kart. 1. Psaní izraelského tisku v srpnu 1963 o revizich politických procesů v ČSSR ve vztahu k Izraeli. Tel Aviv, 5. 9. 1963, s. 1-2. Čj. 120988. 
schůzce československého chargé d'affaires Milana Jurzy s vedoucím východoevropského odboru izraelského ministerstva zahraničních věcí Avidanem v ř́ijnu 1963. ${ }^{100}$

Kromě známých př́padů v Československu vězněných izraelských občanů Mordechaje Orena a Šimona Orensteina se jednalo např́íklad o bývalého izraelského chargé d'affaires v Praze Arie L. Kubovyho. Dalším diplomatickým pracovníkem obviňovaným československými autoritami z nepřátelských aktivit proti státu byl bývalý I. tajemník izraelského vyslanectví v Praze Zeev Shek, jehož jméno bylo v průběhu politických procesů opakovaně akcentováno. ${ }^{101}$ Nové projednávání případu Šimona Orensteina bylo zahájeno v únoru 1963, přičemž Nejvyšší soud rozhodl o zrušení rozsudku ze 7. srpna 1953 a všech dalších rozhodnutí, která na tento rozsudek navazovala. Jako hlavní argument pro revizi případu se uvádělo usnesení soudu, podle kterého popsané jednání Orensteina nelze klasifikovat jako trestný čin. ${ }^{102} \mathrm{Ke}$ znovuotevření př́padu Mordechaje Orena došlo 19. záŕí 1963, kdy stejně jako v prrípadě Orensteina Nejvyšší soud došel k závěru, že původní rozsudek z roku 1953 porušil platná právní ustanovení, a byl proto zrušen stejně jako všechna další návazná rozhodnutí. Prezidium Nejvyššího soudu mimo jiné konstatovalo, že v Československu nikdy žádné spiklenecké centrum neexistovalo, a že všechna obvinění byla účelově vykonstruována. ${ }^{103}$

Stejně jako v předchozích letech československé ministerstvo zahraničních věcí velmi kriticky hodnotilo snahy izraelského vyslanectví o navázání kontaktů s československými občany židovského původu. V květnu 1965 pozval izraelského chargé d'affaires Jehudu Nassieho na osobní schůzku vedoucí 9. odboru ministerstva zahraničních věcí František Zachystal, který vyjádřil ostř̌e formulovanou stížnost vůči aktivitám II. tajemníka izraelského vyslanectví v Praze Karla Yaarona. Dle Zachystalových informací měl Yaaron mezi československými Židy šírit nedovolené tiskoviny a některým z nich i vyplácet blíže neurčené finanční částky jako odměnu za to, že budou přesvědčovat lidi ve svém okruhu k emigraci do Izraele. Zachystal zdůraznil, že pokud by Yaaron ve své činnosti pokračoval, československé úruady by jej musely prohlásit za persona non grata. Chargé d'affaires Nassie přislíbil celou věc projednat jak s Yaaronem, tak

100 AMZV TO-T, Izrael, 1960-1964, kart. 2. Záznam o rozhovoru vedoucího ZÚ Tel Aviv s vedoucím východoevropského odboru izraelského MZV p. Avidanem. Tel Aviv, 24. 10. 1963, 1-2. Čj. 030432.

101 Tamtéž, s. 1-2.

102 ABS, Vyšetřovací spis ORENSTEIN ŠIMON, kart. 2. Rozsudek jménem republiky. Praha, 7. 2. 1964, s. 1-5. Čj. ZV-171 MV.

103 ABS, Zvláštní vyšetřovací spisy - archivní protokol. Rozsudek jménem republiky. Praha, 19. 9. 1963, s. 1-5. Čj. ZV-82. 
s nadřízenými v Izraeli. ${ }^{104}$ Zůstává otevřenou otázkou, do jaké míry se jednalo o reálné aktivity izraelských diplomatů, a do jaké míry byly podobné události československou stranou vykonstruovány či př́mo zveličeny.

Dalším bodem, který se mezi diplomaty obou zemí opakovaně diskutoval, byla stále intenzivnější spolupráce mezi Československem a arabskými skupinami vyhraňujícími se proti židovskému státu. Izrael především velmi negativně hodnotil nárůst československé podpory pro Organizaci pro osvobození Palestiny, která reprezentovala významnou část palestinského nacionalistického hnutí. Na zvyšující se počet pozitivně laděných článků o Organizaci pro osvobození Palestiny a jejím vůdci Jásiru Arafatovi v československém tisku si při osobní schůzce se zástupcem vedoucího 9. odboru Žabokrtským v červnu 1966 oficiálně stěžoval izraelský chargé d'affaires Nassie. V odpovědi mu však byl sdělen obvyklý alibistický argument, že tisk v Československu nepodléhá cenzuře, a proto není v moci československé vlády v této záležitosti jakkoliv intervenovat. ${ }^{105}$

Oproti tomu jako konkrétní příklad pozitivně se rozvíjející kulturní spolupráce v 2. polovině 60 . let lze uvést plánované oslavy výročí tisíce let židovského osídlení na československém území a současně sedm set let od založení Staronové synagogy v Praze, které mělo připadnout na rok 1969. V Návrhu politicko-organizačního usměrnění oslav 1000. výročí založení synagogy v Praze z 6. června 1966 se objevila konkrétní doporučení, jakým způsobem by tyto oslavy měly probíhat, ale současně poznámka, že tato událost může být velmi dobře využita propagandisticky: „Je to vzácný prrípad vzájemného pochopení a shody mezi socialistickým státem a židovskou náboženskou společností. Náboženská svoboda je nejen zaručena zákonem, nýbrž i materiálně zabezpečena státem. Návštěvníci se také přesvědčí, jakou péči věnují státní orgány zachování historických kulturních památek a seznámí se s živým ohlasem židovské tematiky v české kultuře“106.

Celkem se plánovalo rozeslat více než 100 pozvánek do 25 různých zemí, přičemž se počítalo s reprezentací na vysoké politické úrovni, kupříkladu za Československo se měl zúčastnit předseda vlády Jozef Lenárt. V kontextu československo-izraelských vztahů v daném období je charakteristické, že tato pozvání se neměla vztahovat na významné izraelské politické činitele, ale výhradně na důležité náboženské představitele a významné židovské osobnosti českosloven-

104 NA A ÚV KSČ 1945-1989, KTAN-II, kart. 109. Záznam o rozhovoru vedoucího 9. t. o. se chargé d'affaires Státu Izrael Yehuda Nassie dne 10. května 1965. Praha, 10. 5. 1965, s. 1-3. Čj. 024339.

105 AMZV TO-T, Izrael, 1965-1969, kart. 1. Záznam z návštěvy izraelského chargé d'affaires u zástupce ved. 9. t. o. dr. Žabokrtského dne 13. 6. 66. Praha, 13. 6 1966. Čj. 024767.

106 AMZV TO-T, Izrael, 1965-1969, kart. 1. Oslavy 1000. výročí usídlení Židů v Praze - návrh. Praha, 6. 6. 1966, s. 2. Čj. 024441. 
ského původu. ${ }^{107}$ Kromě již zmiňované propagandy Československa tak mělo být zabráněno otevření soudobých citlivých politických otázek akcentovaných ve vztazích Československa a Izraele. ${ }^{108}$

Již na podzim 1966 se však při přípravách objevil první problém, který souvisel s plánovanou zvláštní emisí šesti známek s židovskými motivy, které měly být vydány $\mathrm{v}$ prosinci téhož roku. Náměstek ministra zahraničních věcí Gregor vydání známek nedoporučil z obav možného negativního dopadu na arabsko-československé vztahy: „Po posouzení námětu této emise jsem dospěl $k$ závěru, že jeji vydáni by mohly mit nepřijemné důsledky ve státech, které se cití být ohroženy sionismem, t.j. ve státech celé arabské oblasti. “ ${ }^{109} \mathrm{~K}$ zastavení veškerých př́prav oslav došlo v roce 1967 v kontextu událostí šestidenní války a jejich dopadu na vzájemné vztahy mezi Československem a Izraelem. I to je jednoznačným důkazem, že ačkoliv oficiálně byly tyto oslavy prezentovány jako jednoznačně kulturní událost bez politických souvislostí, realita byla jiná.

Mimo linii oficiálních diplomatických vztahů mezi Československem a Státem Izrael se v menší míre vyvinula spolupráce mezi československou diplomacií a některými dalšími (především levicově orientovanými) izraelskými subjekty. Za nejdůležitější lze označit Komunistickou stranu Izraele (KSI) založenou v roce 1948. Určitým limitem však bylo, že KSI nikdy v izraelském parlamentu nezískala významnější pozice. Přesto docházelo k pravidelné komunikaci mezi československými diplomaty v Tel Avivu a izraelskými komunisty. Nejvýznamnější z nich, jako např́klad předseda KSI Šmuel Mikunis či poslanec za KSI Meir Vilner, dokonce opakovaně obdrželi pozvání k oficiální návštěvě Československa. ${ }^{110}$

Tradičním problémem KSI byl nedostatek finančních prostředků, zásahem do rozpočtu strany pak byly predevším parlamentní volby a s nimi související náklady na propagaci. Vedení KSI proto usilovalo o získání finanční podpory od spřátelených socialistických zemí. V roce 1961 KSI požádala Československo o pomoc ve výši 15 až 20 tisíc IL, ale tato žádost byla prezidentem Novotným striktně zamítnuta. ${ }^{111} \mathrm{~V}$ roce $1964 \mathrm{v}$ kontextu připravovaných voleb do izraelského parlamentu již Československo reagovalo na žádost o pomoc pozitivně

107 Tamtéž, s. 3-4.

108 Tamtéž, s. 6.

109 NA A ÚV KSČ 1945-1989, KTAN-II, kart. 109. Zpráva o př́pravě vydat zvláštní emisi známek $k$ tisíciletému výroči trvání židovské obce v Praze lfotokopie známek přiloženy, postoj MZV/. Praha, 25. 11. 1966, s. 2. Čj. 028561.

110 NA A ÚV KSČ 1945-1989, KTAN-II, k. 109. Záznam o setkání V. Kouckého s M. Vilnerem, členem PB ÚV KS Izraele /žádost o pomoc KSI, některé otázky činnosti strany, 11. 9. 1964. Čj. 4210.

111 NA A ÚV KSČ 1945-1989, KTAN-II, k. 109. Telegram z Tel Avivu, 17. 4. 1961. Čj. 5081. 
a schválilo zaslání pomoci pro KSI ve zboží v hodnotě do 30000 Kčs a kopírovacího stroje v ceně $325000 \mathrm{Kčs} .{ }^{112}$

V roce 1965 však došlo k závažnému vnitřnímu rozkolu uvnitř KSI, který de facto vedl k rozdělení strany na dvě skupiny. Důvodem bylo rozdílné vnímání jednotlivých zahraničně-politických kroků Sovětského svazu zejména s ohledem na kritický př́istup k Izraeli. Zatímco převážná většina židovských členů KSI vedená Moše Snehem a Šmuelem Mikunisem trvala na uznání existence Státu Izrael, radikální křídlo KSI vedené Emilem Habíbím, Taufíkem Túbím a Meirem Vilnerem se plně identifikovalo s postoji Sovětského svazu, což mimo jiné znamenalo intenzivní kritiku vlády izraelského premiéra Levyho Eškola a podporu vybraných arabských zemí jako Alžírska nebo Egypta, které projevily alespoň částečnou sounáležitost $\mathrm{s}$ principy socialismu. $\mathrm{V}$ důsledku těchto rozporů došlo k rozdělení KSI, kdy radikální křídlo utvořilo novou politickou stranu Rakah, která posléze získala oficiální uznání Sovětského svazu a všech dalších socialistických států včetně Československa. ${ }^{113}$

\section{Přerušení diplomatických vztahů Československa a Izraele v roce 1967}

Události Šestidenní války, která se odehrála 5. - 10. června 1967, významným způsobem změnily nejen mapu blízkovýchodního regionu, ale i diplomatické vztahy Izraele s jinými státy. Již nějakou dobu před zahájením vojenských operací byl na Blízkém východě patrný vzestup napětí mezi Izraelem a arabskými státy. Izraelská vláda vedená premiérem Levym Eškolem vnímala jako zásadní nebezpečí rostoucí militarizaci sousedních arabských států a prohlubování vazeb mezi nimi, což chápala jako př́pravu na válku s cílem zničit židovský stát. Dodnes zůstává poměrně kontroverzní otázkou, do jaké míry bylo toto podezření opodstatněné, ale faktem zůstává, že Izrael se v této věci nakonec rozhodl nečekat na výsledky diplomatických vyjednávání a 5. června 1967 zahájil vojenskou operaci Moked, která si v první fázi kladla za cíl zasáhnout významné strategické a vojenské cíle v Egyptě, Jordánsku a Sýrii. ${ }^{114}$

Výsledky Šestidenní války lze hodnotit jako jednoznačné vítězství Izraele, který nejenže uhájil svou existenci a demonstroval svou vojenskou sílu, ale současně dosáhnul znovuotevření Tiranské úžiny a znatelně rozšířil své území o východní Jeruzalém, Západní břeh, Golanské výšiny, pásmo Gazy a Sinajský poloostrov. Izrael v průběhu tohoto konfliktu zaznamenal 779 padlých, oproti tomu

112 NA A ÚV KSČ 1945-1989, KTAN-II, k. 109. Pomoc Komunistické straně Izraele, 10. 10. 1964, s. 1. Čj. 4381.

113 AMZV TO-T, Izrael, 1965-1969, k. 1. Politická zpráva č. 4 - KSI situační zpráva, 18. 5. 1966, s. 1. Čj. 073.

114 OREN, Michael. Six Days of War: June 1967 and the Making of the Modern Middle East. Oxford: Rosetta Books, 2010, s. 171. ISBN 9780345461926. 
arabské ztráty se odhadují na 21000 osob. Takto rychlé a přesvědčivé vítězství významným způsobem zvýšilo prestiž Izraele i sebevědomí židovského národa. Na druhou stranu však měla Šestidenní válka řadu dopadů na další vývoj v regionu. Některé z problémů, jejichž kořeny lze hledat v událostech souvisejících s Šestidenní válkou, ovlivňují regionální politiku do současnosti. ${ }^{115}$

V kontextu dosavadních vztahů mezi Izraelem a státy východního bloku není př́liš překvapivé, že izraelský postup byl těmito státy od počátku hodnocen nikoliv jako sebeobrana, ale jako akt agrese. Československo izraelskou vládu již v květnu 1967 varovalo před zahájením vojenských operací a vyjádřilo svou jednoznačnou podporu arabským státům: ,,V souvislosti se současnou nebezpečnou situaci na Blízkém a Středním východě je ministerstvo zahraničních věcí zplnomocněno prohlásit, že vláda Československé socialistické republiky a její lid - stejně jako mírumilovné národy celého světa - má mimořádný zájem na zachováni míru a bezpečnosti v této oblasti světa. Odsuzuje proto imperialistické intriky a válečné hrozby Izraele na adresu arabských zemí a vyslovuje arabskému lidu svou plnou solidaritu a podporu. "116

Československý prezident Antonín Novotný na sjezdu Komunistické strany Československa 5. června jednoznačně odmítnul izraelský postup. O den později veřejně zaujala stejné stanovisko i československá vláda, která vyzvala Izrael k okamžitému uzavření příměří a zahájení vyjednávání o míru v souladu s př́íslušnými rezolucemi OSN. Současně se objevilo varování, že postup Izraele vážně ohrožuje vztahy mezi Československem a Izraelem. Tento postoj byl oficiálně tlumočen izraelskému chargé d'affaires v Praze Jehudovi Nassiemu. ${ }^{117}$ Nassie v reakci na tento vývoj 7. června předal zástupcům československé diplomacie dopis izraelského premiéra Levyho Eškola určený československému prezidentovi a předsedovi vlády. V tomto dopise Eškol představoval důvody Izraele pro zahájení vojenské operace, které vysvětloval jako nutnou sebeobranu před plánovaným útokem Egypta, a zároveň žádal o mezinárodní podporu. ${ }^{118}$ Československá diplomacie Eškolovy argumenty okamžitě odmítla a setrvala na svém předchozím hodnocení izraelského postupu jako agrese.

Již 10. června 1967 Československo zaslalo izraelské vládě telegram in claris, ve kterém ji informovalo o přerušení vzájemných diplomatických styků. $\mathrm{O}$ den později byla zaslána depeše československému chargé d'affaires $\mathrm{v}$ Tel Avivu Jiř́mmu Skoumalovi s instrukcemi ohledně dalšího postupu. Prioritou byl

115 GILBERT, Martin. Izrael: dějiny. Praha: BB art, 2002, s. 388. ISBN 8072577409.

116 NA A ÚV KSČ 1945-1989, KTAN-II, kart. 109. Návrh prohlášení MZV ČSSR $k$ situaci na Blizkém a Středním východě. Praha, 25. 5. 1967, s. 2-3. Čj. 111454.

117 AMZV TO-T, Izrael, 1965-1969, kart. 1. Izrael - poselství ministerského předsedy. Praha, 8. 6. 1967 , s. 2. Čj. 024225.

118 Tamtéž, s. 1. 
okamžitý odlet veškerého personálu zastupitelského úřadu s výjimkou jednoho člena diplomatického sboru, který měl zůstat v Izraeli několik málo dalších dní, aby mohl dořešit majetkové a další záležitosti spojené s uzavřením vyslanectví. Izraelské straně byly $\mathrm{v}$ tomto kontextu nabídnuty stejné podmínky s ohledem na jejich zastupitelský úřad v Praze. Zastupování Československa v Izraeli mělo nadále probíhat prostřednictvím jiného státu, konkrétně Rakouska. ${ }^{119} \mathrm{~V}$ reakci na Šestidenní válku nedošlo $\mathrm{k}$ přerušení vzájemných vztahů pouze mezi Izraelem a Československem, ale také mezi Izraelem a dalšími evropskými socialistickými zeměmi. Výjimku představovalo jen Rumunsko, které své diplomatické vztahy s Izraelem udrželo aktivní po celé období studené války.

V roce 1967 byla ze strany socialistických států, které se rozhodly své diplomatické vztahy s Izraelem přerušit, snaha o určitou koordinaci jak v politických, tak v praktických záležitostech. Zatímco na politické úrovni se tento cíl podařilo naplnit, na úrovni praktické již tato snaha tolik úspěšná nebyla. Původní plán byl takový, že do Izraele bude vysláno sovětské letadlo, se kterým společně odcestuje většina personálu jednotlivých zastupitelských úr̆adů. Reálná situace ale nakonec byla jiná, protože k vyslání sovětského speciálu do Izraele nedošlo, a jednotlivé státy musely řešit odjezdy svého diplomatického personálu separátně. V př́ípadě Československa se to podařilo 15. června díky zajištění letenek u společnosti Swiss Air. Oproti tomu převoz majetku ambasád proběhl koordinovaně díky vyslání bulharské lodi Dzerdžinskij, která připlula do Izraele v ten samý den. ${ }^{120}$

V důsledku těchto událostí došlo k oslabení vazeb mezi Československem a izraelskými komunisty, kteří do té doby disponovali politickou a částečně i materiální podporou od československé vlády. Vedení komunistické strany Rakah vyjadřovalo velký zájem na udržení nějaké formy vztahů s Československem. Vedoucí představitel této strany Meir Vilner navrhnul, aby do budoucna vzájemná nepř́má komunikace probíhala prostřednictvím československého zastupitelského úřadu ve Vídni nebo v Římě, přes který by bylo možné zasílat zprávy. Tento postup československá strana schválila a jako styčný úřad vybrala své velvyslanectví ve Vídni. ${ }^{121}$

V omezené míře se tak podařilo udržet vzájemné vztahy izraelských a československých komunistických představitelů i ve zbývající etapě studené války. Oproti tomu byla pozastavena činnost krajanského spolku Ligy izraelsko-česko-

119 AMZV TO-T, Izrael, 1965-1969, kart. 1. Izrael - Instrukce pro ZÚ Tel Aviv. Praha, 12. 6. 1967. Čj. 024818.

120 Tamtéž.

121 NA A ÚV KSČ 1945-1989, KTAN-II, kart. 109. Záznam o rozhovoru tajemníka ÚV KSČ soudruha V. Kouckého s členem politického byra ÚV KS Izraele soudruhem Davidem Cheninem. Praha, 14. 7. 1967, s. 3-4. Čj. 2579. 
slovenského prátelství122 navzdory protestům jejího předsedy Chanana Rozena. K jejímu obnovení došlo až 21. února 1990 pod pozměněným názvem Společnost př́telství Izrael - Česko-Slovensko. Po rozdělení Československa došlo k přejmenování organizace na Izraelskou společnost př́tel České republiky, což je název, pod kterým funguje do současnosti. ${ }^{123}$

\section{Závěr}

Politické a diplomatické vztahy mezi Československem a Izraelem v 60. letech 20. století úzce navazovaly na trendy předcházejícího období. Za charakteristický rys vztahů mezi oběma zeměmi lze označit konstantní nedůvěru a podezírání protivníka z nepřátelských úmyslů, což se projevovalo v opakovaných obavách ze vzájemného vypovězení diplomatů, v hodnocení návrhů na zlepšení vzájemných vztahů jako neupř́mných a v neposlední řadě ve vzrůstající podpoře vybraných palestinských skupin v probíhajícím arabsko-izraelském konfliktu.

Výše popsaný stav do značné míry odrážel realitu studené války, kdy na počátku 60. let již bylo evidentní, že Izrael se v blízké budoucnosti s velkou pravděpodobností nestane členem tábora socialistických zemí. Přesto však Československo na vztahy s židovským státem až do roku 1967 zcela nerezignovalo, prričemž kromě monitorovací činnosti situace $\mathrm{v}$ oblasti a podpory izraelských komunistů se Československo ve vztahu k Izraeli zaměřovalo především na zachování status quo.

Tento postup byl v souladu se sovětskými instrukcemi, protože politické vedení v Moskvě si neprálo eskalaci ve vztazích Izraele a zemí východního bloku, tak jak tomu bylo v první polovině 50. let. Existovala patrná snaha vyvarovat se možným nařčením z antisemitismu a náboženské netolerance vůči židovským menšinám, které se nacházely na území většiny socialistických států. V realitě však byli př́islušníci těchto skupin dlouhodobě sledováni tajnými službami, což vzhledem k doposud živé historii pronásledování Židů totalitními režimy vnímala izraelská diplomacie jako potenciální nebezpečí. Je možné konstatovat, že udržení pokud možno fungujících diplomatických československo-izraelských vztahů bylo ve sledovaném období větší prioritou pro Izrael než pro Československo. $\mathrm{V}$ této době byl zaznamenán nárůst počtu židovských migrantů, kterým

122 Tento spolek oficiálně existoval od roku 1948, přičemž původně sdružoval všechny československé migranty bez ohledu na politické názory. Na počátku 50. let však v jeho vedení převážili izraelští komunisté. Liga československo-izraelského prátelství se pak stala platformou propagující oficiální československý režim především prostřednictvím kulturních akcí.

123 Krajanské organizace. In Velvyslanectví České republiky v Tel Avivu, 2015 [online]. Dostupné na internetu: <http:/www.mzv.cz/telaviv/cz/kultura_a_skolstvi/krajanske_organizace_1/ index.html > 
byl legálně umožněn odchod do Izraele. Údaje pro jednotlivé roky se liší, ale jednalo se řádově o stovky emigrantů.

V 60. letech se ve vzájemných československo-izraelských vztazích objevil nový vlivný faktor, a to bylo postupné sbližování se Izraele se SRN, což Československo od počátku tvrdě kritizovalo. Důvodem nebyl pouze spor o to, který z obou německých států by měl být výhradním představitelem německého lidu, Československo současně kritizovalo dle svého soudu nedostatečnou denacifikaci, která v SRN po skončení 2. světové války proběhla. Všechna tato témata se znovu otevřela po zatčení nacistického zločince Adolfa Eichmanna, kdy Československo stejně jako další socialistické země čelilo dilematu, jak se v dané situaci zachovat. Na jednu stranu se československá diplomacie distancovala od jakéhokoliv otevřeného uznání izraelského soudu probíhajícího v Jeruzalémě, avšak současně jeho př́slušnost ani oficiálně neodmítla $\mathrm{z}$ obav, že by takové odmítnutí mohlo být interpretováno jako podpora Eichmanna a jeho zločinů.

Období druhé poloviny 60. let až do událostí Šestidenní války lze označit jako nepř́liš dramatické na události. Díky určité liberalizaci politického a společenského života v Československu dokonce došlo k určitému nárůstu vzájemných kontaktů $\mathrm{v}$ oblasti kulturních vztahů. V porovnání s předchozím obdobím se mnohem častěji povolovaly různé kulturní akce, které nějakým způsobem souvisely s židovskou tématikou, přičemž nejvýznamnější z nich se měly stát prripravované oslavy výročí tisíce let židovského osídlení na československém území plánované na rok 1969. V důsledku politických událostí roku 1967 však byly př́ípravy této kulturní akce zrušeny.

Šestidenní válka, která se odehrála v červnu 1967, představovala v československo-izraelských vztazích bod zlomu. Československo navzdory všem argumentům vlády v Jeruzalémě tuto izraelskou vojenskou operaci odsoudilo jako jednoznačnou agresi vůči zainteresovaným arabským státům. Již 10. června 1967, tedy v poslední den operace, Československo zaslalo izraelské vládě diplomatickou nótu, ve které ji informovalo o přerušení vzájemných diplomatických styků, uzavření vyslanectví a okamžitém odjezdu československého chargé d'affaires Jiř́ho Skoumala s celým personálem ze země. Stejný postup zvolily i všechny ostatní evropské socialistické země, s výjimkou Rumunska. Od této chvíle se Československo zaměřilo na jednoznačnou podporu všech protiizraelsky profilujících se států a skupin. Období vzájemného antagonismu mezi Československem a Izraelem přetrvalo až do roku 1989, kdy v návaznosti na změnu vládnoucího režimu v Československu a přehodnocení zahraničně-politických priorit státu došlo 9. února 1990 k opětovanému navázání vzájemných vztahů.

Závěrem lze tedy konstatovat, že probíhající liberalizace politických a společenských poměrů v Československu se v zahraniční politice vůči Izraeli projevila pouze částečně. $\mathrm{V}$ prípadě významných zahraničně-politických událostí jako 
byl proces s Adolfem Eichmannem a události Šestidenní války, ale i s ohledem na běžnou diplomatickou agendu, lze československo-izraelské vztahy i nadále označit jako velmi chladné. S ohledem na vztahy kulturní a status židovského obyvatelstva v Československu však je možné zaznamenat určité zlepšení. Tento vývoj byl nicméně přerušen vypovězením vzájemných diplomatických vztahů $\mathrm{v}$ roce 1967.

* Vznik tohoto článku byl podpořen projektem Československá zahraniční politika vůči vybraným rozvojovým zemím (SP317118) řešeným v roce 2017 v rámci Interní grantové agentury Fakulty regionálního rozvoje a mezinárodních studií, Mendelovy univerzity v Brně.

\section{DIE STELLUNG DER TSCHECHOSLOWAKISCHEN DIPLOMATIE ZU ISRAEL IN DEN JAHREN 1960-1967}

\section{EVA TATEROVÁ}

Die diplomatischen Beziehungen zwischen der Tschechoslowakei und dem Staaten Israel während des Kalten Krieges hatten eine Reihe von Turbulenzen, die durch große Dynamik geprägt wurden, die weitgehend den Verlauf des Kalten Krieges widerspiegelte.

Dieser Artikel zielt im Detail darauf die Entwicklung der bilateralen politischen und diplomatischen Beziehungen zwischen den beiden Ländern in den Jahren 1960-1967 zu beschreiben und zu verstehen. Thema der tschechoslowakisch - israelischen Beziehungen in dieser Zeit wird nur wenig verarbeitet, trotz einer reichen bestehenden Basis der archivalischen Quellen. Eines der Ziele dieses Textes ist es also die noch nicht veröffentlichen Fakten zu diesem Thema zu präsentieren. Die 60er Jahre des 20. Jahrhunderts waren in der Tschechoslowakei durch partielle Liberalisierung und die Freisetzung des kommunistischen Regimes in vielen Bereichen wie Politik, Wirtschaft und Kultur geprägt. Dieser Prozess gipfelte in Jahren 1967-1968 durch den sogenannten Prager Frühling, die später durch Intervention der Truppen des Warschauer Paktes unterbrochen wurde. Diese Änderungen spiegelten sich nur teilweise in der Einstellung der Tschechoslowakei zu Israel wider.

Während in Bereichen wie Tourismus und kulturelle und wissenschaftliche Zusammenarbeit konnte man eine deutliche Steigerung der Interaktionen bemerken, in den wichtigen Fragen der gegenwärtigen internationalen Beziehungen, wie der Prozess mit Adolf Eichmann oder die Entwicklung des arabisch-israelischen Konflikts, hat immer Tschechoslowakei gegen Israel eher ablehnende Stellung eingenommen

Dieser Trend gipfelte im Juni 1967, wenn sich die Tschechoslowakei als Reaktion auf Ereignisse des Sechstagekrieges entschied, endgültig offizielle diplomatische 
Beziehungen mit Israel einzustellen, dieser Stand dauerte bis zur Änderung des politischen Regimes in der Tschechoslowakei im Jahr 1989.

Mgr. Eva Taterová, M.A., Ph.D.

Ústav teritoriálních studií, Fakulta regionálního rozvoje a mezinárodních studií, Mendelova univerzita $v$ Brně

61300 Brno, Tř́ída gen. Píky 7

e-mail: eva.taterova@mendelu.cz 
Historický časopis, 66, 4, 2018

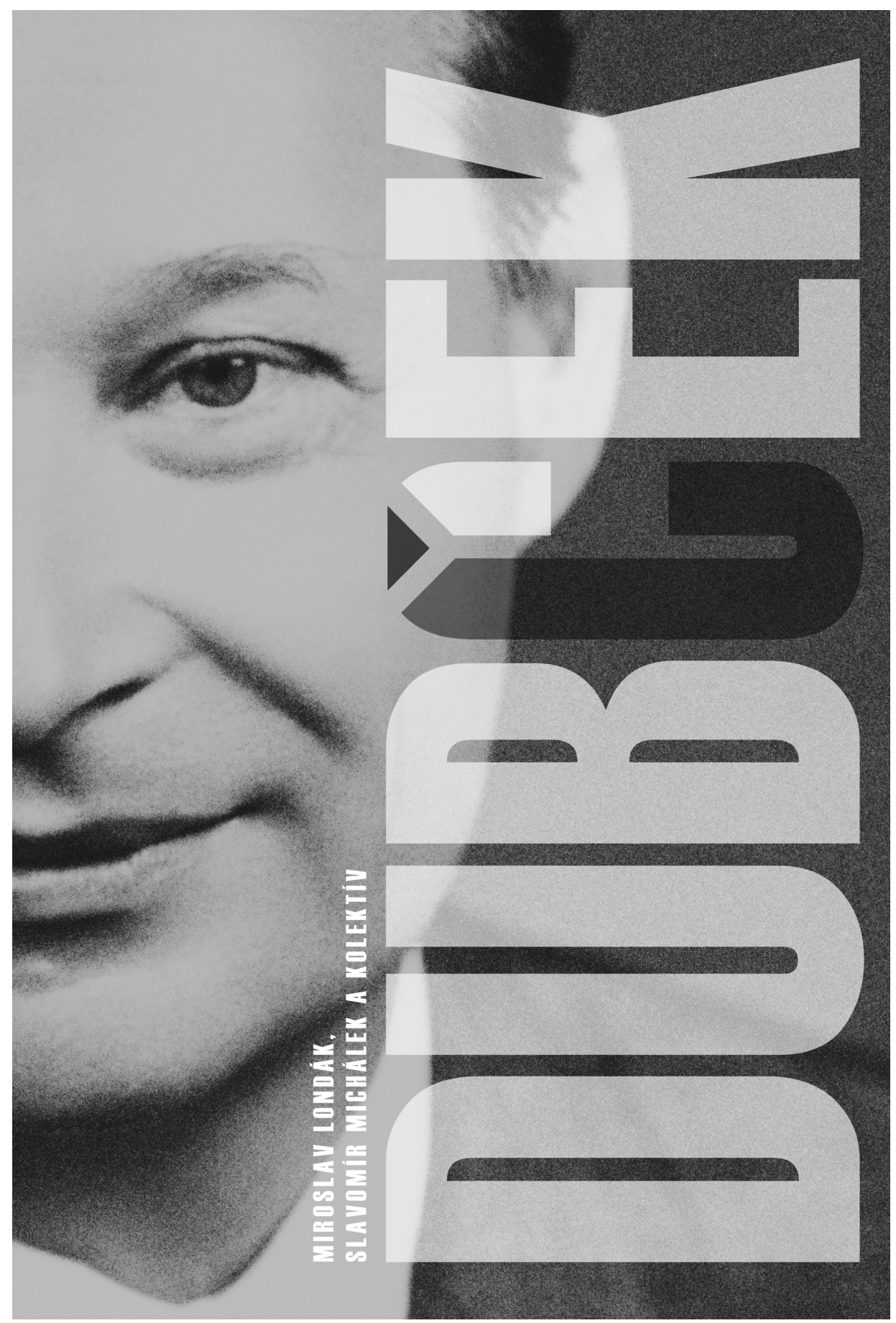

